OPEN ACCESS

Edited by:

O. Adrian Pfiffner,

University of Bern, Switzerland

Reviewed by:

Jeffrey A. Coe,

United States Geological Survey (USGS), United States

Jia-wen Zhou,

Sichuan University, China

Aiguo Xing

Shanghai Jiao Tong University, China

*Correspondence:

Sibylle Knapp

sibylle.knapp@tum.de

Specialty section:

This article was submitted to Structural Geology and Tectonics,

a section of the journal

Frontiers in Earth Science

Received: 02 March 2020

Accepted: 12 June 2020

Published: 03 July 2020

Citation:

Knapp S and Krautblatter $M$

(2020) Conceptual Framework

of Energy Dissipation During

Disintegration in Rock Avalanches.

Front. Earth Sci. 8:263.

doi: 10.3389/feart.2020.00263

\section{Conceptual Framework of Energy Dissipation During Disintegration in Rock Avalanches}

\author{
Sibylle Knapp* and Michael Krautblatter \\ Landslide Research Group, Technical University of Munich, Munich, Germany
}

Rock avalanches usually progress through three consecutive phases: Detachment (Phase 1), Disintegration (Phase 2), and Flow (Phase 3). While significant advances have been achieved in modeling Rock Avalanche Phase 1 (Detachment) and Phase 3 (Flow), the crucial link between both during Phase 2 (Disintegration) is still poorly understood. Disintegration of the detached rock mass is often initiated as soon as sliding starts, and in situ measurements are impossible due to the excessive energy release equivalent to multiple nuclear explosions. Better understanding the energy dissipation during Phase 2 , and the resulting residual kinetic energy that propels the rock avalanche in Phase 3 , is one of the keys to defining the mechanical properties of the avalanche in the runout zone and thus also the resisting force within the avalanche. This paper is a review of our knowledge of energy dissipation in rock avalanches with a focus on processes like friction, collision, fragmentation, comminution, entrainment and explosion during the phase of disintegration. We distinguish between energy sources and sinks and consider not only physical processes, but also chemical alterations that might occur at high temperatures. With that, we make a contribution to improve our understanding of Phase 2 "Disintegration," which is needed for accurately modeling rock avalanches and assessing their hazard potential.

Keywords: rock avalanche, energy dissipation, disintegration, fragmentation, heat, friction, chemical alteration

\section{INTRODUCTION}

Rock avalanches are defined as "extremely rapid, massive, flow-like motion of fragmented rock from a large rock slide or rock fall" (Hungr et al., 2014). Due to their high velocity, volume and runout distance, rock avalanches have a significant impact on human activities in mountain areas, can seriously damage infrastructure and settlements and can cause high numbers of casualties (Evans et al., 2006; Legros, 2006; Hewitt et al., 2008). Landslides resulting from large-scale rock-slope failures are especially hazardous; in the 20th century, disasters of this type have killed more than 50,000 people globally (Evans et al., 2006). As a consequence of increasing population density and the development of infrastructure in mountain areas, the number of elements at risk is growing and accelerating the vulnerability to landslide hazards (Fischer, 1999; Korup, 2005; Hungr, 2006; Legros, 2006). At the same time, the number of massive rock failures from permafrost warming appears to be increasing with potentially disastrous consequences especially when causing rock-ice avalanches with high mobility (Haeberli et al., 2004; Huggel, 2009; Huggel et al., 2012; Krautblatter et al., 2013; Krautblatter and Leith, 2015) or causing flooding after impacting lakes (Haeberli et al., 2016; Knapp et al., 2018). 
Better understanding the disintegration (Phase 2; Figure 1) is key to defining mechanical properties like grain size composition and content of large blocks in the runout zone and therefore the hazard potential of rock avalanches. Current approaches based on Mohr-Coulomb friction models adequately describe the detachment processes (Phase 1; Figure 1) and its energy dissipation (Maddock, 1986) or the rock avalanche flow (Phase 3; Figure 1) utilizing fluid (Bingham) or snow avalanche (Voellmy) analogs with adequate parameterization (Hungr, 2006; Christen et al., 2010; Preuth et al., 2010; Pudasaini and Krautblatter, 2014; Pudasaini and Mergili, 2019). For Phase 2, some models on dynamic fragmentation were just developed (e.g., Zhao et al., 2017; Ghaffari et al., 2019), whereas other disintegration processes, e.g., heat transfer and phase transitions still represent major research gaps. This situation is mainly related to insufficient understanding of energy dissipation during Phase 2, and the resulting residual kinetic energy that propels the ensuing rock avalanche (Phase 3 ). The material properties of the avalanche result from these energetic processes and from the material being overrun. Only by understanding disintegration, will more precise modeling of rock avalanches and their hazard potential be possible. In this paper, we are going to primarily concentrate on the intrinsic properties of rock avalanches that influence disintegration, and we are going to focus on disintegration and energy dissipation in Phase 2, that is directly after the detachment.

\section{ENERGY DISSIPATION DURING DISINTEGRATION}

\section{Disintegration Processes}

Large rock-slope failures usually undergo different stages of downhill movement which may occur consecutively (Abele, 1974): (i) The rock mass moves as a coherent block, and translational shearing occurs along the contact of the bottom of the rock avalanche and the ground surface. (ii) Subsequently, differential movement of individual blocks initiates crushing of the original rock mass. (iii) If the coherent rock mass loses its internal cohesion and disintegrates intensely (shattering) it can evolve into a rapid granular flow (Pollet and Schneider, 2004), which is defined as the distributed shear motion of a group of clasts where individual grains interact with each other and with the boundaries of the moving flow (Dufresne and Davies, 2009). The result can be a highly fragmented (pulverized) rock mass which consists of angular grains of all sizes down to $<1 \mu \mathrm{m}$ (Figures 2A-D; e.g., Davies and McSaveney, 2012).

To decipher individual processes during disintegration, two types of disintegration can be distinguished: (i) static disintegration, a collision-free process driven mainly by gravity, and (ii) dynamic disintegration, referring to particle comminution by grain-to-grain collisions driven by motion. Disintegration refers to fracturing by rapid changes in stress coupled with sudden (un-)loading caused by bending, transverse shearing or delamination of the rock mass creating large blocks, thin vertical slabs or, horizontal sheets, respectively (Erismann and Abele, 2001). Static disintegration is an essential precursor for dynamic disintegration as it creates fractures along which further relative shearing and fragmentation can occur. Shearing along predefined bedding and foliation planes induces shear crushing and the creation of a granular layer.

\section{Energy Sources and Sinks}

Energy dissipation in rock avalanches occurs by transformation of the total energy into thermal energy, acoustic energy or inelastic deformation energy (Nicoletti and Sorriso-Valvo, 1991), where due to the law of energy conservation, the final energy available for mechanical work is less than the initial amount. The energy release is often in the range of dozens to more than a thousand Hiroshima bombs ( $\sim 15 \mathrm{kt}$ TNT or $63 \mathrm{TJ}$ each) for large rock avalanches. Recent work also emphasizes the energy transfer into chemical reactions and phase transitions (Anders et al., 2010; Mitchell et al., 2015). Energy "release" and "consumption" describe the transfer of energy into a different form. Energy in rock avalanches is released by friction, collision and fracturing. Far from a continuous process, energy release is concentrated at points of impact with the ground surface and obstacles where major friction and disintegration of the rock mass is initiated (Erismann and Abele, 2001).

Field conditions constraining energy dissipation can be derived from (i) paleotopography (Nicoletti and Sorriso-Valvo, 1991), (ii) compressive and extensional flow structures in the rock-avalanche deposits (Hewitt, 2006; Dufresne and Davies, 2009; Dufresne et al., 2015), (iii) positions inside the flow recording differences between intact rock and major shear zones (Pollet et al., 2005), (iv) the sedimentological record (Yarnold, 1993; Weidinger et al., 2014) with (v) fine-sediment signatures (Reznichenko et al., 2012), and (vi) melting mineral formation (Weidinger and Korup, 2009). Referring to (i), Nicoletti and Sorriso-Valvo (1991) differentiate dissipation types and rates dependent on geomorphic controls along the runout path: The low-energy dissipative type refers to rock avalanches which are, for example, channelized in narrow valleys. Here, little potential energy is dissipated to other processes than kinetic energy, and mobility is enhanced. The moderate-energy dissipative type refers to radial spreading "free from lateral constraints," resulting in moderate mobility. Finally, the high-energy dissipative type describes running across a narrow valley and impacting against the opposite, at best perpendicular slope, which results in low mobility. Here, most initial energy is dissipated to energy sinks, and only little is left for the transfer into kinetic energy.

During disintegration, $\sim 20-50 \%$ of the potential energy is consumed (Locat et al., 2006; Haug et al., 2016). Considering multiple energy sinks in Figure 1, A-D (friction, inelastic collision, entrainment, and crustal deformation) cause heating to some degree, $\mathrm{E}$ and $\mathrm{F}$ (chemical energy consumption and phase transition) require latent energy for phase transitions, and GI (dust production and bouncing, sound and microseismicity, and momentum exchange) act to export energy outside the impact/disintegration zone. The relative importance of $D, G$, $\mathrm{H}$, and I (compression, dust production and bouncing, sound and microseismicity, and momentum exchange) has yet to be determined, but Erismann and Abele (2001) assumed that they are of minor importance. If $\mathrm{A}-\mathrm{C}$ (friction, inelastic collision, 

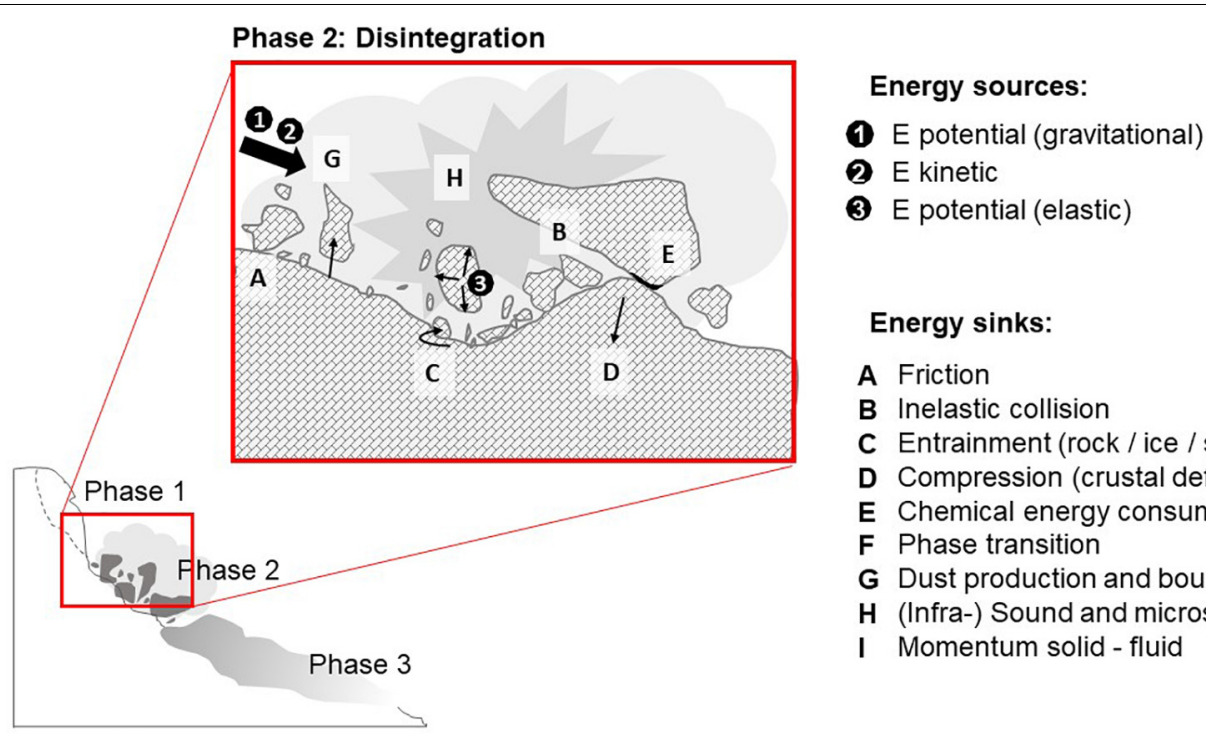

Energy sinks:

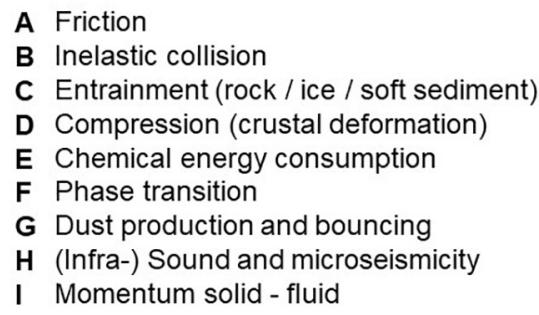

FIGURE 1 | Energy dissipation in Rock Avalanche Phase 2 (Disintegration). The primary energy input to the system is mostly derived from the potential/kinetic energy of the moving rock mass ("Energy sources"). "Energy sinks" cover different types of energy transformation, the majority of which involve heating. (A) Friction. (B) Inelastic collision: breaking at bonds stretching and friction. (C) Entrainment: plowing, scouring. (D) Compression: crustal deformation. (E) Chemical energy consumption: e.g., mineral transformation. (F) Phase transition: solid - fluid - gas, needs latent energy. (G) Dust production and bouncing. (H) Sound and microseismicity. (I) Momentum exchange between solid and fluid phase: energy dissipates to shock wave. The sediment record theoretically shows transitions linked to $(A)-(F)$. (F) and (I) may be present, but cannot be illustrated in the figure. Small arrows indicate direction of energy transfer.

and entrainment) have a major share in the energy dissipation and cause a mean frictional shear resistance whereas $\mathrm{E}-\mathrm{G}$ (chemical energy consumption, phase transformation, and dust production) consume energy for phase transition, the rate of frictional heat generation per unit area $Q$ is

$$
\dot{Q}=\tau v-\phi=\mu_{k} \sigma_{n} v-\phi
$$

where $\tau$ is the average frictional shear resistance, $v$ is the average velocity, $\phi$ is the heat sink-rate due to latent heat, $\mu_{k}$ is the kinetic coefficient of friction and $\sigma_{\mathrm{n}}$ is the normal stress across the sliding plane (Maddock, 1986). Effective latent heat sinks could be from decarbonation of dolomite and calcite in sedimentary rock failures (Mitchell et al., 2015) or from phase transitions of water during melting and vaporization (De Blasio and Medici, 2017). The heat flow away from a source (e.g., a sliding plane) can be calculated by 1D-heat diffusion (Carslaw and Jaeger, 1959; Mitchell et al., 2015), where the temperature increase $\Delta T$ within the observed slip zone is

$$
\Delta T(x, t)=\frac{1}{2 \rho c \sqrt{\kappa \pi}} \int_{0}^{t} \frac{\tau\left(t^{\prime}\right) v\left(t^{\prime}\right)-\phi\left(t^{\prime}\right)}{\sqrt{t-t^{\prime}}} e^{\frac{-x^{2}}{4 \kappa\left(t-t^{\prime}\right)}} d t^{\prime}
$$

where $x$ is the distance from the slip zone, $t$ is time, $\rho$ is mass density, $\kappa$ is thermal diffusivity, $c$ is heat capacity.

\section{Physical Processes}

\section{Fragmentation/Collision/Comminution}

Fragmentation describes the initiation and propagation of fractures and breaking apart and movement of grains (Turcotte, 1997). The related process energy is both linked to the length of the crack extension within existing grains (microcracking) and to the surface energy of the new created grains during comminution (Bieniawski, 1967; Hamdi et al., 2008). Fragmentation occurs as a static (Eberhardt et al., 2004; Wang et al., 2011; Zhang, 2016) or dynamic process (Pollet and Schneider, 2004; Crosta et al., 2007; Imre et al., 2010; Zhang et al., 2019). Static fracture occurs before any collision triggers the disintegration of a mass, whereas dynamic fragmentation shows more intense disintegration, e.g., in shear zones at the base of rock avalanches.

Grains fragment quickly under high local pressures and, thus, general intergranular effective stress and the frictional resistance to shear are reduced (Bowman et al., 2012). In laboratory experiments, the overburden strain-rate is directly related to the fragmentation process. If load is applied sufficiently quickly, particles will dynamically fragment and the kinetic energy of the resulting fragments will cause collisions with surrounding particles. Under dynamic disintegration, kinetic energy is dispersed through the system as colliding particles undergo further fragmentation (Rait and Bowman, 2010). The higher the spatial concentration of simultaneously-fragmenting grains, the lower the effective direct stress on the grain flow (Davies and McSaveney, 2009). Thereby, the basal sliding friction dissipates upward and laterally through the mass, which causes the slabs at the bottom to come to rest first. Thus, slabs higher in the moving mass travel further than the ones lower down (Erismann and Abele, 2001; Pollet and Schneider, 2004). Grainto-grain collisions require an unconfined environment, in which particles can move freely. In such a case the highest levels of friction, crushing and collision occur in the lower part of a rock 


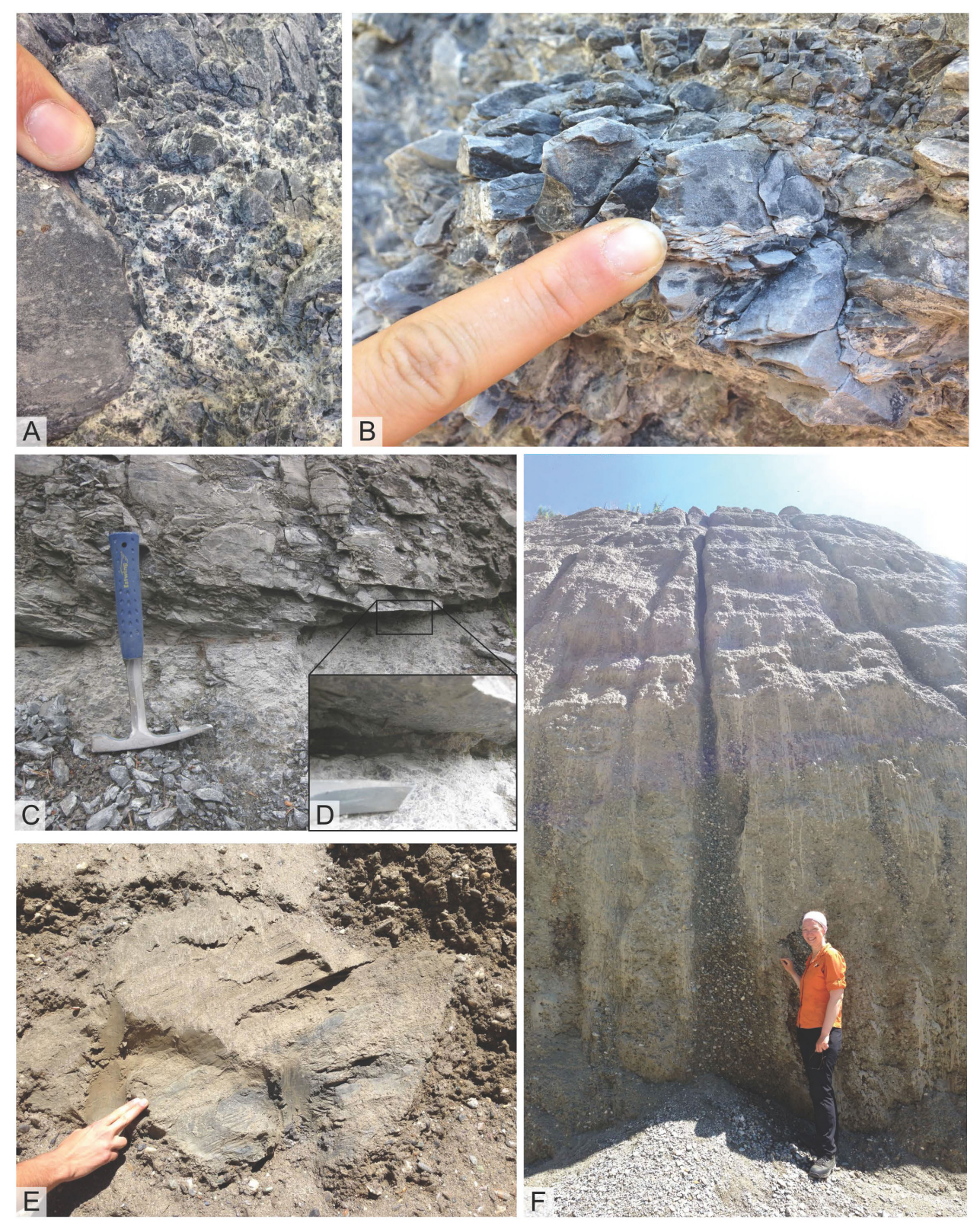

FIGURE 2 | Examples of energy-related features in deposits of the Flims Rock Avalanche (Switzerland): (A) Shattering into cube-like, sharp-angled fragments of different size $(\mathrm{cm}-\mathrm{dm})$ in dark gray Helvetic limestone, secondarily cemented with white matrix of rock powder. (B) "Snapshot" of pulverization with multiple grain-internal layers of micro-shearing. (C,D) Grinding within a shear zone. (E) Entrained lump of lake sediment in the Bonaduz gravel deposits. (F) Vertical Pavoni pipes indicate rapid water discharge after deposition (person for scale).

avalanche due to high compressing forces and large differences in velocity between the moving particles and the ground (Erismann and Abele, 2001). Running on dry rock substrates, it is mainly fragmentation that leads to an increased travel length of the rock avalanche (Pollet and Schneider, 2004; McSaveney and Davies, 2007; Davies and McSaveney, 2009). After Haug et al. (2016), increased fragmentation mostly affects the front of a rock avalanche traveling further, whereas the center of mass crucial for energy considerations, is hardly displaced or decelerates. In comparison to previous papers stating that fragmentation accelerates the flow (Bowman et al., 2012; Langlois et al., 2015), Haug et al. (2016) confirmed that high fragmentation rather favors a more energy-efficient transport mode yielding longer runouts without acceleration.

In either case, fragmentation is considered an "energy sink" (Locat et al., 2006; Crosta et al., 2007; Haug et al., 2016). Haug et al. (2016) propose that static fragmentation may use up to $50 \%$ of the potential energy. Also, Ghaffari et al. (2019) postulate that the kinetic energy is only a small portion of dissipated energy during fragmentation, and the energy rather 
transfers into intergranular collision and friction. Thereby, it is important to note that the energy input for grain-internal "microcracking" weighs far more than for "macro-fragmentation," i.e., the formation of new grains (Ouchterlony et al., 2004; Hamdi et al., 2008). Zhao et al. (2017) quantify the energy dissipation by friction and plastic deformation to $\sim 90 \%$, and the energy needed by bond breakage to $<5 \%$. Plus, the smaller the grain size becomes, the more energy is needed for comminution (Locat et al., 2006). The process of dynamic rock pulverization (Figures 2A-D) consumes massive amounts of energy, e.g., in gouge formation it sums up to $50 \%$ of earthquake energy (Wilson et al., 2005). During grinding, most energy ( $97 \%)$ is converted to heat, with only a small portion $(<1 \%)$ actually contributing to fracturing (Spray, 1992).

\section{Friction/Heat}

Near the base of the moving rock mass, confining forces are largest and so the majority of frictional energy dissipation occurs in this zone (Pollet and Schneider, 2004). Disintegration and heating of the rock mass mainly arise (i) along well-defined persistent shear planes, or (ii) as a total disintegration of the whole mass. Shearing may be localized to a thin, discrete layer and frictional heating of bedrock may reduce basal strength ( $\mathrm{Hu}$ et al., 2018, 2019; Hu and McSaveney, 2018). For (i), a high proportion of the energy release is focused on only a small proportion of the whole mass and will cause significant heating up to a partial melting of clasts, called frictionite (Heuberger et al., 1984; Erismann and Abele, 2001). As soon as particles are $\sim 1 \mu \mathrm{m}$ and below, the amount of heat produced by their elastic and plastic deformation leads to their melting (Spray, 2005). In rare cases (i) this heating can cause centimetre-thick melting of rock and formation of frictionites at temperatures of $1700^{\circ} \mathrm{C}$ (Erismann et al., 1977; Weidinger et al., 2014). Discrete layers of more intense fragmentation contain microbreccias and traces of partial melting (frictionite along shear planes; Schramm et al., 1998; Weidinger and Korup, 2009). For phase transitions, latent energy is absorbed. Besides, frictional shearing is controlled by the production and decay of random kinetic energy during gravitational work (Preuth et al., 2010). Random kinetic energy is referred to the random motion and inelastic interaction between the fragments; it is irreversible because it cannot perform mechanical work (Bartelt et al., 2006; Buser and Bartelt, 2009; Christen et al., 2010). For quantification, Schneider et al. (2010) argue that the total frictional work best correlates with the seismic signal of a rock (-ice) avalanche. The seismograph represents a small, but proportional fraction of this energy loss.

\section{Erosion/Entrainment/Role of Water}

There is an apparent increase in rock-avalanche mobility with volume (e.g., Heim, 1932; Scheidegger, 1973). The volume can be increased either by fragmentation up to 25-30\% (Hungr and Evans, 2004; Crosta et al., 2007) or by the entrainment of substrate material. How enormous the effect of entrainment is, can be shown by the 2000 Tsing Shan event (Hong Kong), where a small volume of $150 \mathrm{~m}^{3}$ of material grew to $1620 \mathrm{~m}^{3}$ because of the strong erosion along the slope (Hungr and Evans, 2004).
Entrainment strongly depends on the character of the path material (Crosta et al., 2009; Aaron and McDougall, 2019) and, for example, may cause high basal shear resistance and momentum loss, when overrunning bedrock or dry bed material (Iverson et al., 2011; Aaron et al., 2017; Whittall et al., 2017; Aaron and McDougall, 2019). In other cases, basal friction is reduced and mobility enhanced (Hungr and Evans, 2004; Aaron and Hungr, 2016; Coe et al., 2016). On the one hand, entrainment is an energy sink because the erosion, uptake and incorporation of material along the travel path by plowing, scouring or even surficial scratching (Hu and McSaveney, 2018) is mechanical work, accompanied by heating. On the other hand, the gain in weight increases the energy budget by acting as an energy source and must not be neglected. Water plays an important role for the amount and rate of entrainment and erosion (Iverson and Ouyang, 2015). Especially for rock avalanches traveling on ice (Huggel et al., 2008; Deline et al., 2015; Bessette-Kirton et al., 2018; Walter et al., 2020) or wet, soft sediments (e.g., lake sediments, Figure 2E), the increased pore pressure enhances the scour of the bed, reduces basal friction and causes velocity, mass and momentum to increase (Iverson et al., 2011; Iverson, 2016; Johnson et al., 2016). Pure ice has a basal friction which is about $75 \%$ lower than that of pure rock. Hence, in rock-ice avalanches, a $\sim 12.5 \%$ reduction of basal friction angle is observed for every $10 \%$ increase in ice content (Sosio et al., 2012). The intergranular direct stress between single grains is reduced by pore-water pressure, i.e., in initially wet sediment more overburden is necessary to start fragmentation than in dry sediment (Abele, 1997). Water may escape quickly after deposition like at the Flims Rock Avalanche (Figure 2F; Pavoni, 1968; Calhoun and Clague, 2018) but increasing temperature may cause water to be pressurized (Voight and Faust, 1982) and/or vaporized, as it is proposed for the Vajont Rockslide (Habib, 1975) or the Köfels Rockslide (De Blasio and Medici, 2017). For the melting of ice, a specific latent heat of $334 \mathrm{~kJ} / \mathrm{kg}$ is needed, and for vaporization $\sim 2265 \mathrm{~kJ} / \mathrm{kg}$, which is almost seven times as much. There is a momentum exchange that consumes energy (Pudasaini and Krautblatter, 2014), and steam explosions are present, but probably camouflaged in the other energy dissipative processes. We have yet to understand the sedimentological imprint of steam explosions in the sediments.

\section{Chemical Processes}

Chemical processes are often neglected in the energy balance of rock avalanches. Novel friction experiments on carbonate rocks, for example, show that at velocities of several meters per second carbon dioxide starts to degas due to thermal decomposition induced by flash heating after only a few hundred microns of slip (Mitchell et al., 2015). This process creates vesicular degassing rims in dolomite clasts and crystalline calcite cement (Anders et al., 2010; Mitchell et al., 2015) and may allow the upper rock mass to slide over a "cushion" of pressurized material. Around $800-850^{\circ} \mathrm{C}$, talc and dolomite start to decompose (Hu et al., 2018) and to produce high-pressure live steam and carbon dioxide (Habib, 1975; Hu et al., 2019). De Blasio and Medici (2017) found bubbles grown in the frictionites 
of the Köfels Rockslide, which they ascribe to water vapor, either due to seeping of vadose water through rock fissures prior to the rock-slope failure, or due to dehydroxylation of the mica, which occurs at $\sim 700^{\circ} \mathrm{C}$ (Alexiades and Jackson, 1967). Also, the existence and relative increase of pyrophyllite on sliding surfaces indicate hydrothermal alteration around $450^{\circ} \mathrm{C}$ (Schäbitz et al., 2015). The accumulation of pyrophyllite at the sliding surface results in reduced shear strength. Also, graphitization (crystallization of amorphous carbon) was recognized in slip zones as phase transformation, which implies frictional heating due to rapid sliding (Oohashi et al., 2011). Graphite is well known as an effective solid lubricant in fault zones with a friction coefficient as low as that of smectite, $\mu=0.1$ (Oohashi et al., 2014).

\section{DISCUSSION OF RESEARCH NEEDS}

Processes during the disintegration phases of rock avalanches are beyond observation, and we have very few analogs that show pressure and temperature conditions inside rock avalanches. Thus, it is likely that we neglect important processes such as steam explosions, partial melting, chemical transitions, and material explosion processes at high pressures.

To systematically decipher relevant processes in rock avalanches, we propose that the energy balance needs to be considered more seriously, since it will help us to reveal energyrelevant processes that we would otherwise neglect. Here we propose to balance the primary energy input to the system constrained by the potential/kinetic energy of the moving rock masses ("Energy sources"). "Energy sinks" include heating, friction, inelastic collision, entrainment, compression during crustal deformation, chemical energy consumption, phase transition solid - fluid - gas, dust production and bouncing as well as sound and microseismicity, and momentum exchange between solid and fluid.

Using an energy balance approach, we can attribute proportions of the energy transmission to certain processes and we can rule out others. However, for this approach, we have to find ways to accurately constrain the $3 \mathrm{D}$ deposition temperature of the rock avalanche by new methods as has been exemplified in a few cases in this paper. The influence of the substrate on types and rates of energy dissipation during disintegration and during the flow represent major research gaps and ask for more studies. For the hazard assessment of rock avalanches, it makes sense not only to differentiate between energy sources and sinks, but also to separate processes that favor mobility and runout length from those which may consume or release energy but do not essentially contribute to the hazard potential. Furthermore, we need to transfer the achievements gained in qualitative assessment toward a more quantitative approach.

Future research in the field should focus on analyzing spatial patterns of disintegration using surface mapping and $3 \mathrm{D}$ subsurface reconnaissance of rock slide/avalanche deposits using geophysical methods at varying scales. Sedimentological analyses reveal abundant information on internal processes, for instance high-stress comminution preserved in fine-sediment signatures (Reznichenko et al., 2012). There is a great demand for study cases with petrographic analysis at microscopic scale (Weidinger et al., 2014), and for such with cross sections through the debris (Locat et al., 2006).

Future research in the laboratory should focus on the implementation of disintegration scenarios in large-scale analog models to help better understand the impact of disintegration and heating on runout length. This way, a conceptual physical (and chemical) model of rock-avalanche disintegration in time and space may be set up in a first step, followed by the implementation in benchmark one- and two-phase runout models.

\section{CONCLUSION}

(1) Due to the law of energy conservation we have a superior tool to decipher processes we have yet neglected in rock avalanches: heating, friction, inelastic collision, entrainment, compression crustal deformation, chemical energy consumption, phase transition solid - fluid - gas, dust production and bouncing as well as sound and microseismicity generation and momentum exchange.

(2) Energy dissipation is concentrated in the disintegration zone where energy estimations indicate considerable heating above $100^{\circ} \mathrm{C}$ of significant portions of the rock mass.

(3) The spatial pattern of heating is characteristic for individual types of movement ranging from concentrated heating by friction along defined sliding planes to diffuse clustered heating in crushing zones near to obstacles.

(4) Massive entrainment where large rockslides drive into, or override, valley sediments also evidently causes crushing and very likely significant heating.

(5) Massive energy dissipation may leave a distinct sedimentological signal detectable in compressive and extensional flow structures, melting or new mineral formation, rock-avalanche structure, material composition, brecciation and fine-sediment signature.

\section{AUTHOR CONTRIBUTIONS}

SK drafted the work, substantially contributed to the conception and design of the work, and acquisition and analysis of literature/data for the work. MK substantially contributed to the concept and revised the work critically for important intellectual content and provided approval for publication. Both authors contributed to the article and approved the submitted version.

\section{ACKNOWLEDGMENTS}

The authors thank Dr. Andreas von Poschinger (Bavarian Environmental Agency, Germany), Prof. John Clague (Simon Fraser University, British Columbia, Canada), and Dr. Anja 
Dufresne (RWTH Aachen, Germany) for longtime and intense discussions on rock avalanches in general, and the Flims Rock Avalanche and Tschirgant Rock

\section{REFERENCES}

Aaron, J., and Hungr, O. (2016). Dynamic analysis of an extraordinarily mobile rock avalanche in the Northwest Territories, Canada. Can. Geotech. J. 53, 899-908. doi: 10.1139/cgj-2015-0371

Aaron, J., and McDougall, S. (2019). Rock avalanche mobility: the role of path material. Eng. Geol. 257:105126. doi: 10.1016/j.enggeo.2019.05.003

Aaron, J., McDougall, S., Moore, J. R., Coe, J. A., and Hungr, O. (2017). The role of initial coherence and path materials in the dynamics of three rock avalanche case histories. Geoenviron. Disasters 4:5.

Abele, G. (1974). Bergsturze in den Alpen - Ihre Verbreitung, Morphologie und Folgeerscheinungen. Wiss. Alpenvereinshefte 25:247.

Abele, G. (1997). Rockslide movement supported by the mobilization of groundwater-saturated valley floor sediments. Z. Geomorphol. 41, 1-20.

Alexiades, C., and Jackson, M. (1967). Chlorite determination in clays of soils and mineral deposits. Am. Mineral. J. Earth Planet. Mater. 52, 1855-1873.

Anders, M. H., Fouke, B. W., Zerkle, A. L., Tavarnelli, E., Alvarez, W., and Harlow, G. E. (2010). The role of calcining and basal fluidization in the long runout of carbonate slides: an example from the Heart Mountain slide block, Wyoming and Montana, USA. J. Geol. 118, 577-599. doi: 10.1086/656383

Bartelt, P., Buser, O., and Platzer, K. (2006). Fluctuation-dissipation relations for granular snow avalanches. J. Glaciol. 52, 631-643. doi: 10.3189/ 172756506781828476

Bessette-Kirton, E. K., Coe, J. A., and Zhou, W. (2018). Using stereo satellite imagery to account for ablation, entrainment, and compaction in volume calculations for rock avalanches on glaciers: application to the 2016 Lamplugh rock avalanche in Glacier Bay National Park, Alaska. J. Geophys. Res. Earth Surf. 123, 622-641. doi: 10.1002/2017jf004512

Bieniawski, Z. (1967). Mechanism of brittle failure of rock Part I-Theory of fracture process. Int. J. Rock Mech. Min. Sci. Geomech. Abstr. 4, 395-406.

Bowman, E. T., Take, W. A., Rait, K. L., and Hann, C. (2012). Physical models of rock avalanche spreading behaviour with dynamic fragmentation. Can. Geotech. J. 49, 460-476. doi: 10.1139/t2012-007

Buser, O., and Bartelt, P. (2009). Production and decay of random kinetic energy in granular snow avalanches. J. Glaciol. 55, 3-12. doi: 10.3189/ 002214309788608859

Calhoun, N. C., and Clague, J. J. (2018). Distinguishing between debris flows and hyperconcentrated flows: an example from the eastern Swiss Alps. Earth Surf. Process. Landforms 43, 1280-1294. doi: 10.1002/esp.4313

Carslaw, H. S., and Jaeger, J. C. (1959). Conduction of Heat in Solids. Oxford: Oxford University Press.

Christen, M., Kowalski, J., and Bartelt, P. (2010). RAMMS: numerical simulation of dense snow avalanches in three-dimensional terrain. Cold Regions Sci. Technol. 63, 1-14. doi: 10.1016/j.coldregions.2010.04.005

Coe, J. A., Baum, R. L., Allstadt, K. E., Kochevar, B. F. Jr., Schmitt, R. G., Morgan, M. L., et al. (2016). Rock-avalanche dynamics revealed by large-scale field mapping and seismic signals at a highly mobile avalanche in the West Salt Creek valley, western Colorado. Geosphere 12, 607-631. doi: 10.1130/ges01265.1

Crosta, G., Imposimato, S., and Roddeman, D. (2009). Numerical modelling of entrainment/deposition in rock and debris-avalanches. Eng. Geol. 109, 135-145. doi: 10.1016/j.enggeo.2008.10.004

Crosta, G. B., Frattini, P., and Fusi, N. (2007). Fragmentation in the Val Pola rock avalanche, Italian Alps. J. Geophys. Res. Earth Surf. 112:F01006. doi: 10.1029/ 2005JF000455

Davies, T., and McSaveney, M. (2012). "Mobility of long-runout rock avalanches," in Landslides: Types, Mechanisms and Modeling, ed. J. J. Clague (Cambridge: Cambridge University Press), 50-58. doi: 10.1017/cbo9780511740367.006

Davies, T. R., and McSaveney, M. J. (2009). The role of rock fragmentation in the motion of large landslides. Eng. Geol. 109, 67-79. doi: 10.1016/j.enggeo.2008. 11.004
Avalanche in particular. We also acknowledge the contributions by three reviewers that helped to improve this manuscript.
De Blasio, F. V., and Medici, L. (2017). Microscopic model of rock melting beneath landslides calibrated on the mineralogical analysis of the Köfels frictionite. Landslides 14, 337-350. doi: 10.1007/s10346-016-0700-z

Deline, P., Hewitt, K., Reznichenko, N., and Shugar, D. (2015). "Rock avalanches onto glaciers," in Landslide Hazards, Risks and Disasters, eds J. F. Shroder, and T. Davies (Amsterdam: Elsevier), 263-319. doi: 10.1016/b978-0-12-396452-6. 00009-4

Dufresne, A., and Davies, T. R. (2009). Longitudinal ridges in mass movement deposits. Geomorphology 105, 171-181. doi: 10.1016/j.geomorph.2008.09.009

Dufresne, A., Prager, C., and Clague, J. J. (2015). “Complex interactions of rock avalanche emplacement with fluvial sediments: field structures at the Tschirgant deposit, Austria," in Engineering Geology for Society and Territory, eds G. Lollino, A. Manconi, J. Clague, W. Shan, and M. Chiarle (Cham: Springer), 1707-1711. doi: 10.1007/978-3-319-09057-3_303

Eberhardt, E., Stead, D., and Coggan, J. (2004). Numerical analysis of initiation and progressive failure in natural rock slopes-the 1991 Randa rockslide. Int. J. Rock Mech. Mining Sci. 41, 69-87. doi: 10.1016/s1365-1609(03)00076-5

Erismann, T., Heuberger, H., and Preuss, E. (1977). Fused rock of kofels (tyrol) frictionite generated by a Landslide. Tschermaks Mineral. Petrogr. Mitteilungen 24, 67-119. doi: 10.1007/Bf01081746

Erismann, T. H., and Abele, G. (2001). Dynamics of Rockslides and Rockfalls. Berlin: Springer.

Evans, S. G., Mugnozza, G. S., Strom, A. L., Hermanns, R. L., Ischuk, A., and Vinnichenko, S. (2006). "Landslides from massive rock slope failure and associated phenomena," in Landslides from Massive Rock Slope Failure, eds S.G. Evans, G. Scarascia Mugnozza, A. Strom, and R.L. Hermanns (Dordrecht: Springer), 03-52. doi: 10.1007/978-1-4020-4037-5_1

Fischer, K. (1999). Massenbewegungen und Massentransporte in den Alpen als Gefahrenpotential: Symposion der Kommission für Geomorphologie der Bayerischen Akademie der Wissenschaften, München, am 24. und 25. München: Borntraeger.

Ghaffari, H., Griffith, W., and Barber, T. (2019). Energy delocalization during dynamic rock fragmentation. Geophys. J. Int. 217, 1034-1046. doi: 10.1093/gji/ ggz064

Habib, P. (1975). Production of gaseous pore pressure during rock slides. Rock Mech. 7, 193-197. doi: 10.1007/bf01246865

Haeberli, W., Buetler, M., Huggel, C., Friedli, T. L., Schaub, Y., and Schleiss, A. J. (2016). New lakes in deglaciating high-mountain regions-opportunities and risks. Clim. Change 139, 201-214. doi: 10.1007/s10584-016-1771-5

Haeberli, W., Huggel, C., Kääb, A., Zgraggen-Oswald, S., Polkvoj, A., Galushkin, I., et al. (2004). The Kolka-Karmadon rock/ice slide of 20 September 2002: an extraordinary event of historical dimensions in North Ossetia, Russian Caucasus. J. Glaciol. 50, 533-546. doi: 10.3189/172756504781829710

Hamdi, E., Romdhane, N. B., du Mouza, J., and Le Cleac'h, J. M. (2008). Fragmentation energy in rock blasting. Geotech. Geol. Eng. 26, 133-146.

Haug, ØТ., Rosenau, M., Leever, K., and Oncken, O. (2016). On the energy budgets of fragmenting rockfalls and rockslides: insights from experiments. J. Geophys. Res. Earth Surf. 121, 1310-1327. doi: 10.1002/2014jf003406

Heim, A. (1932). Landslides and Human Lives (Bergsturz und Menchenleben). Vancouver, BC: Bi-Tech Publishers.

Heuberger, H., Masch, L., Preuss, E., and Schröcker, A. (1984). Quaternary landslides and rock fusion in Central Nepal and in the Tyrolean Alps. Mountain Res. Dev. 4, 345-362.

Hewitt, K. (2006). "Rock avalanches with complex run out and emplacement, Karakoram Himalaya, Inner Asia," in Landslides From Massive Rock Slope Failure, eds S.G.Evans, G.S. Mugnozza, A. Strom, and R.L. Hermanns (Dordrecht: Springer), 521-550. doi: 10.1007/978-1-4020-4037-5_28

Hewitt, K., Clague, J. J., and Orwin, J. F. (2008). Legacies of catastrophic rock slope failures in mountain landscapes. Earth Sci. Rev. 87, 1-38. doi: 10.1016/ j.earscirev.2007.10.002 
Hu, W., Huang, R., McSaveney, M., Yao, L., Xu, Q., Feng, M., et al. (2019). Superheated steam, hot $\mathrm{CO} 2$ and dynamic recrystallization from frictional heat jointly lubricated a giant landslide: field and experimental evidence. Earth Planet. Sci. Lett. 510, 85-93. doi: 10.1016/j.epsl.2019.01.005

Hu, W., Huang, R., McSaveney, M., Zhang, X.-H., Yao, L., and Shimamoto, T. (2018). Mineral changes quantify frictional heating during a large low-friction landslide. Geology 46, 223-226. doi: 10.1130/g39662.1

$\mathrm{Hu}$, W., and McSaveney, M. (2018). A polished and striated pavement formed by a rock avalanche in under $90 \mathrm{~s}$ mimics a glacially striated pavement. Geomorphology 320, 154-161. doi: 10.1016/j.geomorph.2018.08.011

Huggel, C. (2009). Recent extreme slope failures in glacial environments: effects of thermal perturbation. Q. Sci. Rev. 28, 1119-1130. doi: 10.1016/j.quascirev.2008. 06.007

Huggel, C., Clague, J. J., and Korup, O. (2012). Is climate change responsible for changing landslide activity in high mountains? Earth Surf. Process. Landforms 37, 77-91. doi: 10.1002/esp.2223

Huggel, C., Gruber, S., Caplan-Auerbach, S., Wessels, R. L., and Molnia, B. F. (2008). "The 2005 Mt. Steller, Alaska, rock-ice avalanche: a large slope failure in cold permafrost," in Proceedings of the 9th International Conference on Permafrost, Alaska, 747-752.

Hungr, O. (2006). "Rock avalanche occurrence, process and modelling," in Landslides from Massive Rock Slope Failure, eds S.G.Evans, G.S. Mugnozza, A. Strom, and R.L. Hermanns (Dordrecht: Springer), 243-266. doi: 10.1007/9781-4020-4037-5_14

Hungr, O., and Evans, S. G. (2004). Entrainment of debris in rock avalanches: an analysis of a long run-out mechanism. Geol. Soc. Am. Bull. 116, 1240-1252.

Hungr, O., Leroueil, S., and Picarelli, L. (2014). The Varnes classification of landslide types, an update. Landslides 11, 167-194. doi: 10.1007/s10346-0130436-y

Imre, B., Laue, J., and Springman, S. M. (2010). Fractal fragmentation of rocks within sturzstroms: insight derived from physical experiments within the ETH geotechnical drum centrifuge. Granular Matter 12, 267-285. doi: 10.1007/ s10035-009-0163-1

Iverson, R. M. (2016). Comment on "The reduction of friction in long-runout landslides as an emergent phenomenon" by Brandon C. Johnson et al. J. Geophys. Res. Earth Surf. 121, 2238-2242. doi: 10.1002/2016jf003979

Iverson, R. M., and Ouyang, C. (2015). Entrainment of bed material by Earthsurface mass flows: review and reformulation of depth-integrated theory. Rev. Geophys. 53, 27-58. doi: 10.1002/2013rg000447

Iverson, R. M., Reid, M. E., Logan, M., LaHusen, R. G., Godt, J. W., and Griswold, J. P. (2011). Positive feedback and momentum growth during debris-flow entrainment of wet bed sediment. Nat. Geosci. 4, 116-121. doi: 10.1038/ ngeo1040

Johnson, B. C., Campbell, C. S., and Melosh, H. J. (2016). Reply to comment by Iverson on "The reduction of friction in long runout landslides as an emergent phenomenon". J. Geophys. Res. 121, 2243-2246. doi: 10.1002/2016jf00 4093

Knapp, S., Gilli, A., Anselmetti, F. S., Krautblatter, M., and Hajdas, I. (2018). Multistage rock-slope failures revealed in lake sediments in a seismically active Alpine region (Lake Oeschinen, Switzerland). J. Geophys. Res. 123, 658-677. doi: 10.1029/2017jf004455

Korup, O. (2005). Geomorphic hazard assessment of landslide dams in South Westland, New Zealand: fundamental problems and approaches. Geomorphology 66, 167-188. doi: 10.1016/j.geomorph.2004.09.013

Krautblatter, M., Funk, D., and Guenzel, F. (2013). Why permafrost rocks become unstable: a rock-ice-mechanical model in time and space. Earth Surf. Process. Landforms 38, 876-887. doi: 10.1002/esp.3374

Krautblatter, M., and Leith, K. (2015). "Glacier- and permafrost-related slope instabilities," in The High-Mountain Cryosphere: Environmental Changes and Human Risks, eds C. Huggel, M. Carey, J. J. Clague, and A. Kääb (Cambridge: Cambridge University Press), 147-165. doi: 10.1017/cbo97811075886 53.009

Langlois, V. J., Quiquerez, A., and Allemand, P. (2015). Collapse of a twodimensional brittle granular column: implications for understanding dynamic rock fragmentation in a landslide. J. Geophys. Res. 120, 1866-1880. doi: 10. 1002/2014jf003330

Legros, F. (2006). "Landslide mobility and the role of water," in Landslides from Massive Rock Slope Failure (Dordrecht: Springer), 233-242.
Locat, P., Couture, R., Leroueil, S., Locat, J., and Jaboyedoff, M. (2006). Fragmentation energy in rock avalanches. Can. Geotech. J. 43, 830-851. doi: 10.1139/t06-045

Maddock, R. H. (1986). Frictional melting in landslide-generated frictionites (hyalomylonit) and fault-generated pseudotachylites. Tectonophysics 128, 151153. doi: 10.1016/0040-1951(86)90316-1

McSaveney, M., and Davies, T. (2007). "Rockslides and their motion," in Progress in Landslide Science, eds K. Sassa, H. Fukuoka, F. Wang, and G. Wang (Dordrecht: Springer), 113-133. doi: 10.1007/978-3-540-70965-7_8

Mitchell, T. M., Smith, S. A., Anders, M. H., Di Toro, G., Nielsen, S., Cavallo, A., et al. (2015). Catastrophic emplacement of giant landslides aided by thermal decomposition: heart Mountain, Wyoming. Earth Planet. Sci. Lett. 411, 199207. doi: 10.1016/j.epsl.2014.10.051

Nicoletti, P. G., and Sorriso-Valvo, M. (1991). Geomorphic controls of the shape and mobility of rock avalanches. Geol. Soc. Am. Bull. 103, 1365-1373. doi: 10.1130/0016-7606(1991)103<1365: gcotsa > 2.3.co;2

Oohashi, K., Han, R., Hirose, T., Shimamoto, T., Omura, K., and Matsuda, T. (2014). Carbon-forming reactions under a reducing atmosphere during seismic fault slip. Geology 42, 787-790. doi: 10.1130/g35703.1

Oohashi, K., Hirose, T., and Shimamoto, T. (2011). Shear-induced graphitization of carbonaceous materials during seismic fault motion: experiments and possible implications for fault mechanics. J. Struct. Geol. 33, 1122-1134. doi: 10.1016/j. jsg.2011.01.007

Ouchterlony, F., Nyberg, U., Olsson, M., Bergqvist, I., Granlund, L., and Grind, H. (2004). Where does the explosive energy in rock blasting rounds go? Sci. Technol. Energ. Mater. 65, 54-63.

Pavoni, N. (1968). Über die Entstehung der Kiesmassen im Bergsturzgebiet von Bonaduz-Reichenau (Graubünden). Ecol. Geol. Helvetica 6, 494-500.

Pollet, N., Cojean, R., Couture, R., Schneider, J.-L., Strom, A. L., Voirin, C., et al. (2005). A slab-on-slab model for the Flims rockslide (Swiss Alps). Can. Geotech. J. 42, 587-600. doi: 10.1139/t04- 122

Pollet, N., and Schneider, J. L. M. (2004). Dynamic disintegration processes accompanying transport of the Holocene Flims sturzstrom (Swiss Alps). Earth Planet. Sci. Lett. 221, 433-448. doi: 10.1016/s0012-821x(04)00 071-8

Preuth, T., Bartelt, P., Korup, O., and McArdell, B. W. (2010). A random kinetic energy model for rock avalanches: eight case studies. J. Geophys. Res. 115: F03036. doi: 10.1029/2009JF001640

Pudasaini, S. P., and Krautblatter, M. (2014). A two-phase mechanical model for rock-ice avalanches. J. Geophys. Res. 119, 2272-2290. doi: 10.1002/ 2014jf003183

Pudasaini, S. P., and Mergili, M. (2019). A multi-phase mass flow model. J. Geophys. Res. 124, 2920-2942. doi: 10.1029/2019jf005204

Rait, K. L., and Bowman, E. T. (2010). "Dynamic fragmentation in rock avalanches: a numerical model of micromechanical behaviour," in Numerical Methods in Geotechnical Engineering, eds T. Benz and S. Nordal (London: Taylor \& Francis Group), 435-440. doi: 10.1201/b10551-80

Reznichenko, N. V., Davies, T. R. H., Shulmeister, J., and Larsen, S. H. (2012). A new technique for identifying rock avalanche-sourced sediment in moraines and some paleoclimatic implications. Geology 40, 319-322. doi: 10.1130/ g32684.1

Schäbitz, M., Janssen, C., Wirth, R., and Dresen, G. (2015). "Microstructural and geochemical evolution of sliding surfaces in landslides and comparisons with crustal fault zones," in Proceedings of the EGU General Assembly 2015, Vienna.

Scheidegger, A. E. (1973). On the prediction of the reach and velocity of catastrophic landslides. Rock Mech. 5, 231-236. doi: 10.1007/bf013 01796

Schneider, D., Bartelt, P., Caplan-Auerbach, J., Christen, M., Huggel, C., and McArdell, B. W. (2010). Insights into rock-ice avalanche dynamics by combined analysis of seismic recordings and a numerical avalanche model. J. Geophys. Res. 115:F04026. doi: 10.1029/2010JF001734

Schramm, J. M., Weidinger, J. T., and Ibetsberger, H. J. (1998). Petrologic and structural controls on geomorphology of prehistoric Tsergo Ri slope failure, Langtang Himal, Nepal. Geomorphology 26, 107-121. doi: 10.1016/s0169$555 x(98) 00053-1$

Sosio, R., Crosta, G. B., Chen, J. H., and Hungr, O. (2012). Modelling rock avalanche propagation onto glaciers. Q. Sci. Rev. 47, 23-40. doi: 10.1016/j. quascirev.2012.05.010 
Spray, J. G. (1992). A physical basis for the frictional melting of some rock-forming minerals. Tectonophysics 204, 205-221. doi: 10.1016/0040-1951(92)90308-s

Spray, J. G. (2005). Evidence for melt lubrication during large earthquakes. Geophys. Res. Lett. 32:L07301. doi: 10.1029/2004GL022293

Turcotte, D. L. (1997). Fractals and Chaos in Geology and Geophysics. Cambridge: Cambridge university press.

Voight, B., and Faust, C. (1982). Frictional heat and strength loss in some rapid landslides. Geotechnique 32, 43-54. doi: 10.1680/geot.1982.32.1.43

Walter, F., Amann, F., Kos, A., Kenner, R., Phillips, M., de Preux, A., et al. (2020). Direct observations of a three million cubic meter rock-slope collapse with almost immediate initiation of ensuing debris flows. Geomorphology 351:106933. doi: 10.1016/j.geomorph.2019.106933

Wang, S., Sloan, S., Liu, H., and Tang, C. (2011). Numerical simulation of the rock fragmentation process induced by two drill bits subjected to static and dynamic (impact) loading. Rock Mech. Rock Eng. 44, 317-332. doi: 10.1007/s00603-0100123-4

Weidinger, J. T., and Korup, O. (2009). Frictionite as evidence for a large Late Quaternary rockslide near Kanchenjunga, Sikkim Himalayas, India Implications for extreme events in mountain relief destruction. Geomorphology 103, 57-65. doi: 10.1016/j.geomorph.2007.10.021

Weidinger, J. T., Korup, O., Munack, H., Altenberger, U., Dunning, S. A., Tippelt, G., et al. (2014). Giant rockslides from the inside. Earth Planet. Sci. Lett. 389, 62-73. doi: 10.1016/j.epsl.2013.12.017

Whittall, J., Eberhardt, E., and McDougall, S. (2017). Runout analysis and mobility observations for large open pit slope failures. Can. Geotech. J. 54, 373-391. doi: $10.1139 / \mathrm{cgj}-2016-0255$
Wilson, B., Dewers, T., Reches, Z. E., and Brune, J. (2005). Particle size and energetics of gouge from earthquake rupture zones. Nature 434, 749-752. doi: 10.1038/nature03433

Yarnold, J. C. (1993). Rock-avalanche characteristics in dry climates and the effect of flow into lakes: insights from mid-Tertiary sedimentary breccias near Artillery Peak, Arizona. Geol. Soc. Am. Bull. 105, 345-360. doi: 10.1130/00167606(1993) $105<0345$ :racidc $>2.3 . c 0 ; 2$

Zhang, M., Wu, L., Zhang, J., and Li, L. (2019). The 2009 Jiweishan rock avalanche, Wulong, China: deposit characteristics and implications for its fragmentation. Landslides 16, 893-906. doi: 10.1007/s10346-019-01142-6

Zhang, Z.-X. (2016). Rock Fracture and Blasting: Theory and Applications. Oxford: Butterworth-Heinemann.

Zhao, T., Crosta, G. B., Utili, S., and De Blasio, F. V. (2017). Investigation of rock fragmentation during rockfalls and rock avalanches via 3-D discrete element analyses. J. Geophys. Res. 122, 678-695. doi: 10.1002/2016jf004060

Conflict of Interest: The authors declare that the research was conducted in the absence of any commercial or financial relationships that could be construed as a potential conflict of interest.

Copyright $\odot 2020$ Knapp and Krautblatter. This is an open-access article distributed under the terms of the Creative Commons Attribution License (CC BY). The use, distribution or reproduction in other forums is permitted, provided the original author(s) and the copyright owner(s) are credited and that the original publication in this journal is cited, in accordance with accepted academic practice. No use, distribution or reproduction is permitted which does not comply with these terms. 